University of Nebraska - Lincoln

DigitalCommons@University of Nebraska - Lincoln

\title{
The Nuclear Nonproliferation Regime and Nuclear Realities: Repair or Reassessment?
}

Jack M. Beard

University of Nebraska College of Law, jbeard2@unl.edu

Follow this and additional works at: https://digitalcommons.unl.edu/lawfacpub

Beard, Jack M., "The Nuclear Nonproliferation Regime and Nuclear Realities: Repair or Reassessment?" (2007). College of Law, Faculty Publications. 162.

https://digitalcommons.unl.edu/lawfacpub/162

This Article is brought to you for free and open access by the Law, College of at DigitalCommons@University of Nebraska - Lincoln. It has been accepted for inclusion in College of Law, Faculty Publications by an authorized administrator of DigitalCommons@University of Nebraska - Lincoln. 


\title{
The Nuclear NonProliferation Regime and Nuclear Realities: REPAIR OR REASSESSMENT?
}

\author{
By Jack M. Beard*
}

Many observers in 1963 might have viewed the proposition that only nine nations would have nuclear weapons in the year 2007 as highly unlikely. ${ }^{1}$ What prevented the cascade of new nuclear weapons states that was anticipated forty years ago, and how could the answer benefit modern attempts to limit nuclear proliferation? Even though the pillar of the current nonproliferation regime, the Nuclear Non-Proliferation Treaty (the NPT), ${ }^{2}$ may make it somewhat harder or costlier for states to acquire or develop nuclear weapons technology, it is difficult empirically to establish a causal link between the NPT and the limited number of states with nuclear weapons in their arsenals today.

Some commentators praise the NPT regime and assert that it has played a critical, if not all-important, role in constraining nuclear proliferation. Yet in analyzing the reasons behind this phenomenon, it is difficult to disassociate or dismiss other possible interests, issues, or considerations that can also motivate states to forego possession of nuclear weapons. For example, basic factors such as the great expense associated with the development of nuclear weapons or the lack of perceived catastrophic security threats may in some cases discourage states from choosing the nuclear path. Additionally, in a recent case in which restraint failed, the NPT appears to have been largely irrelevant: North Korea simply announced its withdrawal from the treaty in 2003 and then proceeded with the apparently successful development and testing of a nuclear bomb in 2006.

Rather than concluding that the limited number of nuclear states is due to the overarching influence of the NPT regime, much of this restraint may be better explained by other factors, particularly the dynamic effect of the existing geopolitical framework. This framework is dominated by powerful states that continue to maintain nuclear weapons as an indispensable component of their strategic policies, provide security assurances and nuclear umbrellas for their allies, and exert their influence through various instruments, policies, and activities to discourage non-nuclear states from acquiring these weapons. Instead of focusing attention on repair of the NPT regime, history suggests that a more fundamental reassessment of the factors behind nuclear nonproliferation may be appropriate. Such a reassessment also serves to highlight serious tensions intrinsic to the NPT regime.

Bilateral arms control and multilateral disarmament regimes have demonstrated the ability significantly to assist states in reducing or eliminating various types or classes of weapons. To be effective, however, such regimes must be based on sound design elements, impose coextensive obligations on the parties related to the weapons systems to be reduced or

\footnotetext{
* Professorial Lecturer, UCLA Law School.

${ }^{1}$ At a press conference in 1963, President Kennedy remarked that "personally I am haunted by the feeling that by 1970 , unless we are successful, there may be ten nuclear powers instead of four, and by 1975,15 or 20 ." Text of President Kennedy's News Conference on Foreign and Domestic Affairs, N.Y. TIMEs, Mar. 22, 1963, at 4.

${ }^{2}$ Treaty on the Non-Proliferation of Nuclear Weapons, July 1, 1968, 21 UST 483, 729 UNTS 161, entered into force March 5, 1970.
} 
destroyed, and enjoy the meaningful participation of all regime members, especially the most powerful ones. By way of contrast, the NPT is an unusual asymmetrical multilateral disarmament regime that makes the vast majority of states in the world bear the burden of its most serious obligations: these non-nuclear weapons states must ensure that they remain so by refraining from acquiring or transferring restricted technology and by subjecting themselves to various safeguard requirements and controls over their peaceful nuclear activities. In return, access to peaceful nuclear technology is to be encouraged and total nuclear disarmament is to be promoted. Several states explicitly are permitted, however, to keep their nuclear arsenals for an undefined period, subject to the requirement that they "pursue negotiations in good faith on effective measures relating to cessation of the nuclear arms race at an early date and to nuclear disarmament, and on a Treaty on general and complete disarmament under strict and effective international control.",

If nuclear weapons states have no intention of fulfilling their NPT disarmament obligations, the so-called "grand bargain" of the NPT becomes a hollow promise, subjecting the regime to justified criticism by non-nuclear weapons states that it is discriminatory. Such a conclusion has serious, if not fatal, implications for the NPT as a meaningful constraint on nuclear proliferation. Unfortunately, the geopolitical realities associated with nuclear weapons do not correspond with the legal framework envisioned by Article VI of the NPT. Instead of moving towards nuclear disarmament, the nuclear weapons states continue to maintain national security policies centered on nuclear weapons capabilities and the most powerful of these states are more likely to be planning to replace or improve their aging nuclear arsenals than eliminating them. ${ }^{4}$ The utility of nuclear weapons, particularly as instruments of strategic deterrence, thus has complicated treaty-based efforts to abolish them legally and has also impeded the development of a customary international legal norm banning their use in all circumstances. $^{5}$

Some scholars argue that a norm against the proliferation of nuclear weapons and a taboo against their use have served to reinforce each other, advancing the theory that this taboo can play an important part in helping to deter nuclear proliferation. ${ }^{6}$ As is the case in attempting to demonstrate the impact of the NPT's legal restraints, empirically establishing the causal pathways between nuclear nonproliferation and a purported normative restraint is also a problematic undertaking. Even if a taboo against the use of nuclear weapons exists, it is not apparent that it readily translates into a taboo against their development and possession. In fact, several arguments can be made against the existence of any such normative opprobrium being attached to their development and possession, particularly when compared with attitudes towards other weapons that are more widely regarded by the international community as abhorrent.

\footnotetext{
${ }^{3}$ Id., Art. VI.

${ }^{4}$ For example, the Bush Administration recently proposed a multibillion-dollar plan to create a new generation of nuclear warheads. The plan has generated criticism, particularly in the context of the failure of the United States to ratify the Comprehensive Test Ban Treaty. See Walter Pincus, Congress Skeptical of Warhead Plan: Lawmakers and Experts Question Necessity, Implications of a New Nuclear Weapon, WASH. Post, Apr. 22, 2007, at A05 (quoting former Senator Sam Nunn as saying that "If Congress gives a green light to this program in our curren world environment . . . I believe that this will be misunderstood by our allies, exploited by our adversaries, [and] complicate our work to prevent the spread and use of nuclear weapons."').

${ }^{5}$ See Advisory Opinion on The Legality of the Threat or Use of Nuclear Weapons, 1996 ICJ REP. 1, at 33 (" "The emergence, as lex lata, of a customary rule specifically prohibiting the use of nuclear weapons as such is hampered by the continuing tensions between the nascent opinio juris on the one hand, and the still strong adherence to the practice of deterrence on the other.").

${ }^{6}$ See, e.g., Nina Tannenwald, Stigmatizing the Bomb: Origins of the Nuclear Taboo, 29 INT'L SECURITY, No. 4, 5, 41 (Spring 2005).
} 
First, in stark contrast to other multilateral disarmament regimes banning all member states from developing, producing, stockpiling, or otherwise acquiring or retaining a particular type of weapon-such as the regimes banning biological and chemical weapons-the NPT explicitly permits some states to possess nuclear weapons and in so doing makes the prohibition in that agreement less than universal. ${ }^{7}$

Second, unlike biological or chemical weapons, nuclear weapons continue to play a key role in the national security policies of the most powerful states and thus may be seen as conveying a corresponding level of status. Nuclear weapons and important related facilities such as those required for the uranium enrichment process are in fact increasingly viewed by some states as symbols of technical sophistication, prowess, and prestige, rather than as badges of shame or dishonor. ${ }^{8}$ Difficulties in stigmatizing nuclear weapons have been present since they were first used, due in part to their introduction by the victorious allies to defeat a Japanese war of aggression. ${ }^{9}$ In contrast to the revulsion generated by the use of chemical weapons in World War I that led to an international conference banning the use of both chemical and biological weapons in 1925, nuclear weapons unfortunately were embraced after World War II by the leading states of the world and immediately came to be accepted as symbols of power and technological achievement. As such, some countries and cultures may view nuclear weapons in a favorable light, instead of loathing or detesting them. ${ }^{10}$

Finally, even though some cultures and countries may consider nuclear weapons to be repugnant, this does not mean that these cultures and countries are not willing to rely on the nuclear weapons capabilities of their allies for their own security. ${ }^{11}$

While it is difficult empirically to establish that legal constraints and alleged normative prohibitions are the cause of nuclear nonproliferation since 1963, there is no shortage of examples of nuclear weapons states creating disincentives for other states to develop their

\footnotetext{
${ }^{7}$ See Article 1, Convention on the Prohibition of the Development, Production, Stockpiling, and Use of Chemical Weapons and on Their Destruction, Jan. 13, 1993, 32 ILM 800 (the "CWC"); Article 1, Convention on the Prohibition of the Development, Production and Stockpiling of Bacteriological (Biological) and Toxin Weapons and on Their Destruction, Apr. 10, 1972, 26 UST 583, 1015 UNTS 163 (the "BWC"). Although the BWC is deeply flawed by indeterminate language in its key provisions and by a lack of mandatory transparency mechanisms, neither the BWC nor the CWC explicitly exempt any state party from compliance with each regime's respective disarmament obligations. Proponents of a taboo against nuclear weapons concede that the lack of a universal nuclear prohibition in the NPT “departs in some ways from the objective characteristics of a taboo." See e.g., Tannenwald, supra note 6, at 9.

${ }^{8}$ Dr. Mohamed ElBaradei, the Director of the International Atomic Energy Agency, has observed that the uranium enrichment process, which is a key capability in the building of a nuclear weapon, has come to be viewed as a symbol of power and prestige by some states. See Daniel Dombey, Pressure Mounts on Iran over its Nuclear Programme, Fin. TIMEs (London), Feb. 21, 2007 (quoting ElBaradei as saying that "Iran sees enrichment. . . as a strategic goal because they feel that this will bring them power, prestige and influence.")

${ }^{9}$ See Richard Falk, The Challenges of Biological Weaponry: A Twenty-First-Century Assessment, in Biological Warfare and Disarmament, in Biological WaRFare and Disarmament: New Problems/New Perspectives 4142 (Susan Wright ed., 2002).

${ }^{10}$ Whether the underlying motives were perceived strategic needs or national pride, the development and testing of nuclear weapons by India, Pakistan, and North Korea, and questionable nuclear activities being pursued by Iran raise serious questions about the relevance of any nuclear taboo on the decision-makers in these states. See, e.g., John J. Mearsheimer, India Needs The Bomb, N.Y. Trmes, Mar. 24, 2000, at A21 ("India did not acquire these [nuclear] weapons for frivolous reasons, like misplaced pride or domestic politics, as some Americans believe. Rather, India, like the United States, had sound strategic reasons for wanting them."); Simon Rosenblum and Ernie Regehr, The Status of Nuclear Weapons, TORONTO STAR, June 16, 1998, at A19 ("Nuclear weapons by virtue of the legitimacy invested in them by the policies and arsenals of the major nuclear powers, are still thought to convey status, enhance national pride, and force the world to reckon with any state that acquires them. Who can doubt that the people of India and Pakistan feel that the possession of nuclear weapons will put them on the world's political map?'); Karl Vick, Iranians Assert Right To Nuclear Weapons; Issue Unites Conservatives, Reformers, WASH. Post, Mar. 11, 2003, at A16 ("While maintaining that their country is not developing nuclear weapons, Iranians argue strenuously and with rare unanimity that they have a right to such weapons, to balance Israel's arsenal and as a manifestation of national pride.")
} 
own nuclear weapons or providing reasons for them to abandon nascent nuclear weapons programs. ${ }^{12}$ Even those scholars who believe that the NPT is responsible for preventing nuclear anarchy recognize that the security assurances provided by nuclear weapons states have always been an essential part of the larger nuclear non-proliferation regime. ${ }^{13}$ The question presented is whether the NPT has been the driving force behind nuclear nonproliferation or whether it actually has played only a minor role in comparison with other factors, particularly the realpolitik influence wielded by nuclear weapons states.

Beyond the influence that nuclear weapons states can exercise through security assurances and nuclear umbrellas, a variety of other economic, political, and military instruments outside the NPT legal framework continues to be available for these powerful states to advance specific nonproliferation objectives. For example, both the United States and Russia had fundamental interests in ensuring that Belarus, Kazakhstan, and Ukraine took immediate steps to abandon the nuclear arsenals that they inherited from the former Soviet Union. The United States used a spectrum of incentives, assurances, and assistance programs to facilitate the transition of these states to a non-nuclear weapons status. ${ }^{14}$ Under the auspices of one of these instruments, the Cooperative Threat Reduction Program, the United States spent hundreds of millions of dollars assisting in the removal of nuclear weapons, destroying related components, silos, and delivery vehicles, converting some facilities to peaceful uses, and establishing various programs in these states to prevent the proliferation of nuclear weapons technology and expertise. ${ }^{15}$

In another area, the United States continues to advance specific nonproliferation goals through cooperative activities with many states under the Proliferation Security Initiative. This initiative and related projects, which include the coordinated interdiction of shipments of nuclear weapons technology and their delivery systems, have enjoyed some successes and are credited by some with playing a key role in the unraveling of a nascent Libyan nuclear weapons program. ${ }^{16}$ Nuclear weapons states and their allies continue to develop and collaborate on a variety of other multilateral programs outside the NPT framework in an attempt to prevent nuclear nonproliferation. These include the implementation of common guidelines for nuclear exports through the Nuclear Suppliers Group and proposals to limit non-nuclear weapons states' development of sensitive nuclear facilities such as those used for uranium enrichment by providing an assured access to nuclear fuel and related nuclear fuel cycle services.

\footnotetext{
${ }^{11}$ Japan is an example of a country with an understandably strong aversion to nuclear weapons that does not correspond with a national policy of rejecting nuclear protection. Following an apparent North Korean nuclear test, the Japanese government welcomed reassurances by U.S. Secretary of State Condoleezza Rice that " $[t]$ he United States has the will and the capability to meet the full range-and I underscore full range-of its deterrent and security commitments to Japan." Thomas Shanker \& Norimitsu Onishi, Japan Assures Rice That It Has No Nuclear Intentions, N.Y. TIMES, Oct. 19, 2006, at 14. At the same time, Defense Secretary Donald Rumsfeld and South Korean Defense Minister Yoon Kwang Ung approved a joint communiqué that emphasized the "continuation of the extended deterrence offered by the U.S. nuclear umbrella" for South Korea. Glenn Kessler, China Gave 'Strong Message' To North Koreans, Rice Says; Beijing Is Called Ready to Apply U.N. Sanctions, N.Y. TrMEs, Oct. 21, 2006, at A11.

${ }^{12}$ See, e.g., Joseph S. Nye Jr., Nonproliferation After North Korea, WASH. Post, Nov. 5, 2006, at B7 ("'Our allies in Europe and Japan were protected by our nuclear umbrella, and we told South Korea and Taiwan that our willingness to defend them would be jeopardized if they developed the bomb."')

${ }^{13}$ See, e.g., Jozef Goldblat, Arms Control: The New Guide to Negotiations and Agreements 110 (2002).

${ }^{14}$ See, e.g., Bill Keller, The Thinkable, N.Y. Times, May 4, 2003, at 48 ("The first Bush administration and then the Clinton administration bargained hard for the surrender of Ukraine's weapons, promising abundant financial aid and a military partnership that Ukrainians hoped would lead to American security guarantees.').

15 See generally James Clay Moltz, Introduction: Assessing United States Nonproliferation Assistance to the Newly-Independent States, 7 NoNPROLIFERATION REv. 55, 56 (2000), available at <http://cns.miis.edu/pubs/npr/ vol07/71/intro71.htm>.

${ }^{16}$ See David Sanger, U.S. and Russia Will Police Potential Nuclear Terrorists, N.Y. TImEs, July 15, 2006, at A8.
} 
By creating calculated political, economic, and military disincentives for other states, nuclear weapons states thus continue to wield considerable influence in preventing and discouraging other states from acquiring nuclear weapons. While the NPT may offer supporting mechanisms that make it more costly for states to develop or acquire nuclear weapons technology, it is difficult to determine the precise impact of those mechanisms and even more difficult to prove that they have been a decisive factor in nuclear nonproliferation, particularly in comparison with other forces.

As nuclear weapons states continue to maintain security policies centered on their nuclear arsenals, do not seriously contemplate the abolition of nuclear weapons, and take no good faith efforts to achieve disarmament, the NPT legal regime remains divorced from the geopolitical framework in which it operates. To the extent that this gap is widened by actions of the great powers that emphasize the desirability of new or improved nuclear weapons systems and the possibility that more nuclear weapons testing will be required, the NPT is further weakened. Similarly, scholars who believe that it is critically important to maintain a strong taboo against the use of nuclear weapons are concerned that U.S. actions demonstrating continued reliance on nuclear weapons and the need for improved nuclear capabilities are likely to have a corrosive effect on that taboo. ${ }^{17}$

On one level, "repairing"' the centerpiece of the nonproliferation regime, the NPT, is a simple matter: amend the treaty to prohibit the possession of nuclear weapons by all states and require the immediate destruction of these weapons in order to eliminate the threat they pose to all humanity. Although not without a rational basis in a post-Cold War security environment, ${ }^{18}$ such a revision of the NPT regime is highly unlikely to be accepted by nuclear weapons states since it is contrary to their firmly established strategic policies.

Continuing efforts to repair or improve the implementation of the NPT may yield some benefits, ${ }^{19}$ but the regime itself will continue to be undermined by blatant demonstrations of the asymmetrical nature of its rights and obligations. Nuclear weapons states, particularly the United States, could address this problem by taking steps toward decreasing the chasm between their disarmament obligations under the NPT and their current strategic policies and national security priorities. Barring such developments, however, an assessment of future options for dissuading, deterring or preventing new members from joining the nuclear club needs to take into account all the forces that have contributed to nuclear nonproliferation to this point in history and should not exaggerate the impact of the NPT.

${ }^{17}$ See, e.g., Thomas C. Schelling, The Nuclear Taboo, WALl St. J., Oct. 24, 2005, at A14.

${ }^{18}$ See Goldblat, supra note 12, at 112-13 (concluding that arguments for preserving the option of using nuclear weapons against non-nuclear states are "not convincing" and describing as "surprising" the fact that nuclear postures have remained largely unchanged after the end of the Cold War in light of the limited, residual role that nuclear weapons play in deterring only the first use of an enemy's nuclear weapons).

${ }^{19}$ These useful efforts include attempts by the International Atomic Energy Agency to strengthen safeguards agreements and other transparency measures by making them more determinate and comprehensive, particularly in the context of the ongoing controversy surrounding Iran's nuclear activities. 